\title{
PREVALENSI NEMATODA USUS GOLONGAN STH (Soil Transmitted Helminth) PADA MASYARAKAT YANG MENGGUNAKAN KOTORAN SAPI DI DUSUN SADE SEBAGAI BAHAN PEMBERSIH LANTAI
}

\author{
Erna Kristinawati ${ }^{1}$, Yudha Anggit Jiwantoro ${ }^{2}$ \\ ${ }^{12}$ Dosen Jurusan Analis Kesehatan, Poltekkes Kemenkes Mataram, Indonesia
}

\begin{tabular}{l} 
Article Info \\
\hline Article history: \\
Received Feb $05^{\text {th }}, 2020$ \\
Revised Mar $06^{\text {th }}, 2020$ \\
Accepted Mar $09^{\text {th }}, 2020$ \\
\hline
\end{tabular}

\section{Keyword:}

Cow dung

STH

Kato Katz.

\begin{abstract}
PT)
Population health problems in Indonesia are still characterized by high illnesses associated with low socioeconomic levels of the population. One of the diseases with high incidence is worm infection. In Indonesia, helminthiasis is the most public health problem after malnutrition, because Indonesia is an agrarian country with low socioeconomic, knowledge, environmental sanitation and community hygiene conditions which is very supportive of worm infection and transmission. Objective: this study was to determine the prevalence of STH intestinal nematodes in communities using cow dung in Sade Hamlet. Method: his research is a descriptive observational study. The sample consisted of 48 people who used cow dung as a floor cleaner in Sade sub-village, Rembitan Village, Pujut District, Central Lombok Regency. Worm infestation on the fingers is done with a rinse using $\mathrm{NaOH}$, examination of the stool using the Kato Katz method. Results: The results of this study showed positive on STH Nematodes of STH groups in the community in Sade Hamlet using Cow Manure as Floor cleaning material, namely: Trichuris trichiura (4.17\%) and hookworm (10.42\%). Conclusion: The prevalence of intestinal nematodes of the STH group in the Sade Hamlet community was $14.59 \%$.
\end{abstract}

Copyright $\odot$ Jurnal Analis Medika Biosains (JAMBS) All rights reserved.

\section{ABSTRAK}

Masalah kesehatan penduduk di Indonesia masih di tandai dengan tingginya penyakit-penyakit yang berkaitan dengan rendahnya tingkat sosial ekonomi penduduk. Salah satu penyakit yang insidennya masih tinggi adalah infeksi cacing. Di Indonesia kecacingan merupakan masalah kesehatan masyarakat terbanyak setelah malnutrisi, karna Indonesia adalah negara yang agraris dengan tingkat sosial ekonomi, pengetahuan, keadaan sanitasi lingkungan dan higiene masyarakat masih rendah yang sangat menyokong untuk terjadinya infeksi dan penularan cacing. Tujuan: penelitian ini adalah untuk mengetahui Prevalensi Nematoda usus golongan STH pada masyarakat yang menggunakan kotoran sapi di Dusun Sade. Metode: Penelitian ini bersifat observasional deskriptif. Sampel berjumlah 48 orang masyarakat yang menggunakan kotoran sapi sebagai pembersih lantai di dusun Sade, Desa Rembitan, Kecamatan Pujut, Kabupaten Lombok Tengah. Pemeriksaan kecacingan pada jari-jari tangan dilakukan dengan bilasan menggunakan $\mathrm{NaOH}$, pemeriksaan pada feses menggunakan metode Kato Katz. Hasil: Hasil penelitian ini menunjukkan positif pada Nematoda Usus Golongan STH pada masyarakat di Dusun Sade yang menggunakan Kotoran Sapi sebagai bahan pembersih Lantai yaitu: Trichuris Trichiura (4,17\%) dan hook worm (10,42\%). Kesimpulan: Prevalensi Nematoda Usus golongan STH pada masyarakat Dusun Sade sebesar 14,59\%.

Kata Kunci: Kotoran Sapi, STH, Kato Katz.

Copyright $\odot$ Jurnal Analis Medika Biosains (JAMBS) 



\section{Pendahuluan}

Kecacingan merupakan penyakit yang disebabkan oleh parasit cacing yang dapat membahayakan kesehatan. Penyakit kecacingan yang sering menginfeksi dan memiliki dampak yang sangat merugikan adalah infeksi cacing yang di tularkan melalui tanah atu sering di sebut "Soil Transmitted Helminth (STH)". STH sendiri masih dianggap tidak membahayakan atau menyebabkan kematian. Namun pada kenyataannya dampak dari infeksi STH dapat menyebabkan penurunan kesehatan bahkan kematian (Depkes RI, 2010).

Infeksi kecacingan akan mempengaruhi pemasukan, pencernaan, penyerapan, dan metabolisme makanan. Selain itu, infeksi cacing dapat menimbulkan kekurangan gizi berupa kalori dan protein, serta kehilangan darah yang berakibat menurunnya daya tahan tubuh dan menimbulkan gangguan tumbuh kembang anak (Samudra, 2013).

Masalah kesehatan penduduk di Indonesia masih di tandai dengan tingginya penyakit-penyakit yang berkaitan dengan rendahnya tingkat sosial ekonomi penduduk. Salah satu penyakit yang insidennya masih tinggi adalah infeksi cacing. Di Indonesia kecacingan merupakan masalah kesehatan masyarakat terbanyak setelah malnutrisi, karna Indonesia adalah negara yang agraris dengan tingkat sosial ekonomi, pengetahuan, keadaan sanitasi lingkungan dan higiene masyarakat masih rendah yang sangat menyokong untuk terjadinya infeksi dan penularan cacing (Ginting,2003).

Di Indonesia infeksi cacing masih merupakan masalah besar dalam kesehatan masyarakat karena prevalensi nya masih tinggi yaitu kurang lebih 45-65\%, sedangkan diwilayah yang memiliki sanitasi lingkungan buruk, panas dan kelembaban tinggi prevalensi infeksi cacing biasa mencapai 80\% (Ali,2007).

STH (Soil Transmitted Helminth) adalah cacing golongan nematoda yang memerlukan tanah untuk perkembangan bentuk infektif. Di Indonesia golongan cacing ini yang amat penting dan menyebabkan masalah kesehatan pada masyarakat adalah cacing gelang (Ascaris lumbricoides) penyakitnya disebut Ascariasis, cacing cambuk (Trichuris trichiura) penyakitnya disebut Trichuriasis, Strongyloide stercoralis penyakitnya disebut Strongiloidiasis cacing tambang (Ancylostoma duodenale dan Necator americanus) penyakitnya disebut Ankilostomiasis dan Nekatoriasis. Infeksi STH ditemukan tersering di daerah iklim hangat dan lembab yang memiliki sanitasi dan hygiene buruk yang hidup di usus dan telurnya akan keluar melalui tinja hospes. Jika hospes defekasi di luar (taman, lapangan) atau jika tinja mengandung telur dibuahi maka telur tersebut akan tersimpan dalam tanah. Telur menjadi infeksius jika telur matang. Saat ini lebih dari 2 milyar penduduk di dunia terinfeksi cacing. Prevalensi yang tinggi ditemukan terutama di negara-negara non industri (negara yang sedang berkembang). Menurut laporan World Health Organisation (WHO) pada tahun 2012 memperkirakan lebih dari 1,5 miliar orang atau 24\% dari populasi dunia terinfeksi dengan cacing yang ditularkan melalui tanah yang ditularkan di seluruh dunia (WHO,2015).

Infeksi cacingan yang sering adalah "Soil Transmitted Helminthes (STH)" yang merupakan infeksi cacing usus yang ditularkan melalui tanah atau dikenal sebagai penyakit cacingan. Spesies cacing STH antara lain Ascaris lumbricoides (cacing gelang), Trichuris trichiura (cacing cambuk), Ancylostoma duodenale dan Necator americanus (cacing tambang) (Gandahusada, 2006).

Tinggi rendahnya frekuensi kecacingan berhubungan erat dengan kebersihan pribadi dan sanitasi lingkungan yang menjadi sumber infeksi. Diantara cacing usus yang menjadi masalah kesehatan adalah kelompok 'Soil Transmitted Helmint' atau cacing yang ditularkan melalui tanah, seperti Ascaris 
lumbricoides, Trichuris trichiura dan Ancylostoma sp (cacing tambang) merupakan penyebab terjadinya transmisi telur cacing dari tanah kepada manusia melalui tangan atau kuku yang mengandung telur cacing, lalu masuk ke mulut bersama makanan. Di Indonesia prevalensi kecacingan masih ting gi antara 60\%-90\% tergantung pada lokasi dan sanitasi lingkungan (Mardiana dan Djarismawati,2008).

Salah satu desa yang sanitasinya tidak memadai adalah Dusun Sade. Hal ini dikarenakan kotoran sapi bukan hal yang menjijikkan bagi warga suku sasak di Dusun Sade, Desa Rembitan, Kecamatan Pujut, Kabupaten Lombok Tengah, Nusa Tenggara Barat. Novelti pada penelitian ini adalah pada Dusun Sade, kotoran sapi atau kerbau mereka gunakan sebagai pembersih lantai rumah. Kebiasaan masyarakat di Dusun Sade membersihkan lantai rumah dengan limbah sapi atau kerbau ini dilakukan sebulan sekali oleh kaum perempuan suku sasak yang telah berkeluarga.

Kotoran sapi mengandung hemisellulosa sebesar 18,6\%, sellulosa 25,2\%, lignin 20,2\%, nitrogen $1,67 \%$ fosfat $1,11 \%$ dan kalium sebesar 0,56\%, Kotoran sapi mempunyai C/N sebesar 16,6-25\%. Menurut Hartono (2009) rentang rasio $\mathrm{C} / \mathrm{N}$ antara 25-30 merupakan rentang optimum untuk proses penguraian anaerob. Jika rasio $\mathrm{C} / \mathrm{N}$ terlalu tinggi, maka nitrogen akan terkonsumsi sangat cepat oleh bakteri-bakteri metanogen untuk memenuhi kebutuhan protein dan tidak akan bereaksi dengan sisa karbonnya. Sebagai hasilnya produksi gas akan rendah. Di lain pihak jika rasio $\mathrm{C} / \mathrm{N}$ sangat rendah nitrogen akan dibebaskan dan terkumpul dalam bentuk $\mathrm{NH}_{4} \mathrm{OH}$.

\section{Metode Penelitian}

Jenis metode penelitian yang di gunakan adalah Penelitian ini merupakan penelitian Observasional deskriptif dengan menggunakan rancangan cross sectional yaitu melakukan observasi dan pengukuran variabel pada satu waktu tertentu. Cara pengumpulan data sekaligus dalam suatu waktu dengan tujuan mencari hubungan antara variabel dependen (infeksi Soil Transmitted Helminth) dengan variabel independen (pertumbuhan dan status anemia pada masyarakat di dusun sade, desa rembitan, kecamatan pujut, kabupaten lombok tengah) (Sastroasmoro, 2014). Pada penelitian ini yang ingin diketahui oleh peneliti adalah prevalensi nematoda usus golongan STH pada masyarakat yang menggunakan kotoran sapi di Dusun Sade sebagai bahan pembersih lantai. Kemudian data yang di peroleh di analisis secara deskriptif. Uji etik penelitian telah peneliti lakukan di Komisi Etik Poltekkes Kemenkes Mataram.

\section{Hasil Penelitian dan Pembahasan}

Data Hasil pemeriksaan Hasil pemeriksaan nematoda usus pada feses dan bilasan jari-jari tangan dapat dilihat pada tabel 1 sampai tabel 3 dibawah ini:

Tabel 1. Hasil pemeriksaan nematoda usus pada sampel feses masyarakat di dusun Sade yang menggunakan kotoran sapi sebagai bahan pembersih lantai.

\begin{tabular}{|c|l|c|c|}
\hline \multirow{2}{*}{ No } & \multirow{2}{*}{ Jenis Nematoda Usus } & \multicolumn{2}{|c|}{ Hasil Pemeriksaan } \\
\cline { 3 - 4 } & & Jumlah & Persentase (\%) \\
\hline 1 & Ascaris lumbricoides & 0 & 0 \\
\hline 2 & Trichuris trichiura & 2 & 4,17 \\
\hline
\end{tabular}


ISSN: 2656-2456 (Online)

ISSN: 2356-4075 (Print)

\begin{tabular}{|c|l|c|c|}
\hline 3 & Hookworm & 0 & 0 \\
\hline 4 & Lain-lain & 0 & 0 \\
\hline 5 & Negatif & 46 & 95,83 \\
\hline 6 & Total & 48 & 100 \\
\hline
\end{tabular}

Tabel 2. Hasil pemeriksaan Nematoda Usus pada sampel bilasan jari-jari tangan pada masyarakat Dusun Sade yang menggunakan kotoran sapi sebagai bahan pembersih lantai.

\begin{tabular}{|c|l|c|c|}
\hline \multirow{2}{*}{ No } & \multirow{2}{*}{ Jenis Nematoda Usus } & \multicolumn{2}{|c|}{ Hasil pemeriksaan } \\
\cline { 3 - 4 } & & Jumlah & Persentase \\
\hline 1 & Ascaris lumbricoides & 0 & 0 \\
\hline 2 & Trichuris trichiura & 0 & 0 \\
\hline 3 & Hookworm & 5 & 0 \\
\hline 4 & Lain-lain & 43 & 89,58 \\
\hline 5 & Negatif & 48 & 100 \\
\hline 6 & & & \\
\hline
\end{tabular}

Tabel 3. Hasil pemeriksaan Nematoda Usus pada sampel feses dan bilasan jari-jari tangan masyarakat Dusun Sade yang menggunakan kotoran sapi sebagai bahan pembersih lantai.

\begin{tabular}{|c|l|c|c|}
\hline \multirow{2}{*}{ No } & \multicolumn{2}{|c|}{ Jenis Nematoda Usus } & \multicolumn{2}{|c|}{ Hasil pemeriksaan (feses dan bilasan jari-jari tangan) } \\
\cline { 3 - 4 } & & Jumlah & Persentase \\
\hline 1 & Ascaris lumbricoides & 0 & 0 \\
\hline 2 & Trichuris trichiura & 2 & 4,17 \\
\hline 3 & Hook worm & 5 & 10,42 \\
\hline 4 & Lain-lain & 0 & 0 \\
\hline 5 & Negatif & 41 & 85,41 \\
\hline 6 & $\quad$ Total & 48 & 100 \\
\hline
\end{tabular}

Tabel 1. menunjukkan dari 48 sampel didapatkan hasil positif pada feses sebanyak 2 sampel, yaitu ditemukan telur cacing jenis trichuris trichiura sebanyak 4,17\% sedangkan pada sampel lainnya ditemukan hasil negatif 95,83\%. Tabel 2. menunjukkan dari 48 sampel didapatkan hasil positif pada bilasan jari-jari tangan sebanyak 5 sampel, yaitu ditemukan telur cacing jenis hook worm sebanyak 10,42\%. Sedangkan pada sampel lainnya ditemukan hasil negatif 89,58\%. Tabel 3. menunjukkan dari 48 sampel didapatkan hasil positif pada sampel sebanyak 7 sampel, yaitu ditemukan telur cacing jenis Trichuris trichiura (4,17\%) dan hook worm (10,42\%). 
Sedangkan pada 46 sampel lainnya ditemukan hasil negatif $85,41 \%$. Sehingga prevalensi nematoda usus pada masyarakat Dusun Sade yang menggunakan kotoran sapi sebagai bahan pembersih lantai adalah 14,59\%.

\section{Pembahasan}

Dusun Sade merupakan sala satu dusun yang sanitasinya kurang memadai. karena masih menggunakan kotoran sapi sebagi pembersih lantai, kotoran sapi bukan hal yang menjijikkan bagi warga suku sasak di Dusun Sade. Kotoran sapi atau kerbau justru mereka gunakan sebagai pembersih lantai rumah. Kebiasaan masyarakat di Dusun Sade membersihkan lantai rumah dengan limbah sapi atau kerbau ini dilakukan sebulan sekali oleh kaum dewasa suku sasak yang telah berkeluarga.

Hasil Pemeriksaan Laboratorium menunjukkan bahwa dari 48 sampel feses dan 48 sampel jari jari tangan pada masyarakat di Dusun Sade Desa Rembitan Kecamatan Pujut didapatkan prevalensi 14,59\%. Jenis infeksi kecacingan yang dapat diidentifikasi adalah Trichuris trichiura (4,17\%) dan Hook worm (10,42\%).

Infeksi trichuris trichiura merupakan yang tertinggi di bandingkan hook Worm. Beberapa hasil penelitian lain yang dilakukan di Indonesia menunjukkan hasil yang berbeda, pada umumnya Hook Worm merupakan infeksi yang tertinggi, kemudian diikuti trichuris trichiura. Tingginya infeksi trichuris trichiura didukung oleh beberapa hal kondisi lingkungan yang sesuai bagi perkembangan cacing, siklus hidup trichuris trichiura yang tidak memerlukan hospes perantara menjadikannya lebih mudah menginfeksi manusia, sedangkan hook worm disebabkan karena keadaan sanitasi lingkungan yang kurang baik serta tingkat pendidikan yang masih rendah dan kurangnya kepedulian terhadap kebersihan pribadi dan lingkungan.

Angka kecacingan pada warga di Dusun Sade Desa Rembitan Kecamatan pujut ini dapat di pengaruhi oleh beberapa faktor seperti kurang menjaga kebersihan lingkungan, kurang menjaga kebersihan pribadi, kebiasaan tidak memakai alas kaki, mengkonsumsi jajanan atau makanan di lingkungan rumah terkadang jarang mencuci tangan terlebih dahulu, hal ini sesuai dengan penelitian yang telah dilakukan antara lain oleh Didik S.,2010, bahwa infeksi cacing usus ditularkan melalui tanah yang tercemar telur cacing, tempat tinggal dan cara hidup yang tidak bersih merupakan masalah kesehatan masyarakat.

Infeksi yang disebabkan oleh cacing Ascaris lumbricoides dan trichuris trichiura biasanya ringan tidak menimbulkan gejala klinis yang jelas dan parasit itu ditemukan pada pemeriksaan feses secara rutin. Prevalens penyakit kecacingan dapat ditekan serendah mungkin dengan mengendalikan faktor lingkungan tanpa mengesampingkan faktor perilaku. Menurut Achamadi (2005), bahwa penyakit kecacingan merupakan penyakit berbasis lingkungan. Untuk mengendalikan diperlukan upaya perbaikan sanitasi lingkungan yang diikuti dengan upaya perbaikan hidup sehat. 


\section{Kesimpulan}

Ditemukan telur cacing Nematoda Usus golongan STH pada masyarakat Dusun Sade yang menggunakan kotoran sapi sebagai bahan pembersih lantai yaitu: Trichuris Trichiura (4,17\%) dan hook worm (10,42\%). dan Prevalensi nematoda usus golongan STH pada masyarakat Dusun Sade yang menggunakan kotoran sapi sebagai bahan pembersih lantai sebesar $14,59 \%$.

\section{Daftar Pustaka}

Ali, AR. 2008. Penyakit Cacing Pada Anak SD di Polewali Mandar Tahun 2006-2007. http://www.arali2008.wordpress.com buku II. Prestasi Pustaka. Jaya Pura.

Depkes RI. (2010) Profil Kesehatan Indonesia 2009. Jakarta

Gandahusada, Srisasi. 2006. Parasitologi Gerakan Terpadu Pengentasan Kemiskinan daerah.

Ginting S. 2002. Cacing dan perumahan. [home-page on internet]. [diakses pada 23 Maret 2009]. Available from: http:// www. Journal. Unair.ac.id.

Mardiana, Djarismawati. Prevalensi Cacing Usus Pada Ibu Hamil. Jurnal 2008.

Sastroasmoro S. 2014. Dasar-Dasar Metodologi Penelitian Klinis Edisi 5. Jakarta: Sumatera Utara Universitas Indonesia. Jakarta.

WHO. 2015. Helminthiasis [Diakses 20 Agustus 2016]. Tersedia Dari:174-86. 6-11. 